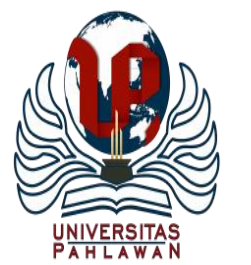

Edukatif : Jurnal Ilmu Pendidikan Volume 3 Nomor 3 Tahun 2021 Halm 839 - 846 EDUKATIF: JURNAL ILMU PENDIDIKAN

Research \& Learning in Education

https://edukatif.org/index.php/edukatif/index

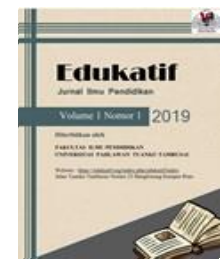

\title{
Kebijakan Pemerintah Terhadap Kondisi Pendidikan di Indonesia Pada Masa Orde Lama (Periode 1945 - 1966)
}

\author{
Hawa Kurnia ${ }^{1 凶}$, Hudaidah ${ }^{2}$ \\ Universitas Sriwijaya, Indonesia ${ }^{1,2}$

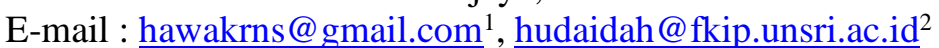

\begin{abstract}
Abstrak
Tujuan kajian ini adalah untuk mengetahui kebijakan pemerintah terhadap pendidikan Indonesia pada periode orde lama (periode 1945 - 1966). Kajian ini menggunakan jenis deskriptif kualitatif dengan metode penelitian studi kepustakaan, yaitu suatu cara pengumpulan data di perpustakaan, dengan menggunakan karya ilmiah, buku, jurnal serta artikel lainnya yang berhubungan dengan penelitian. Hasil penelitian membahas mengenai kebijakan pemerintah terhadap kondisi pendidikan pada masa orde lama. Periode orde lama sendiri berlangsung dari tahun 1945 sampai tahun 1965 dibawah kekuasaan presiden Soekarno. Pemerintah pada periode ini mengeluarkan banyak kebijakan terhadap pendidikan nasional. Setelah proklamasi, pendidikan di Indonesia berlandaskan UUD 1945 serta Pancasila yang baru saja menjadi falsafah negara. Salah satunya pasal 31 UUD tahun 1945 yang mengatur tentang penyelenggaraan pendidikan. Untuk sistem pendidikan, periode ini diteruskan seperti zaman penjajahan Jepang. Namun untuk rencana pembelajaran sama seperti pada umumnya serta bahasa Indonesia disahkan sebagai bahasa pengantar resmi untuk sekolah. Dapat disimpulkan pendidikan di era orde lama berkembang lebih signifikan dari masa sebelumnya, terlihat dari kebijakankebijakan yang dibuat dalam membangun struktur pendidikan nasional Indonesia yang kuat.
\end{abstract}

Kata Kunci: Pendidikan, Kebijakan Pemerintah, Orde Lama.

\begin{abstract}
The purpose of this study is to determine government policies towards Indonesian education during the Orde Lama period (1945-1966). This study uses a descriptive qualitative type with the research method of literature study, which is a way of collecting data in the library, using scientific works, books, journals and other articles related to research. The results of the study discuss the government's policy on the condition of education during the Orde Lama era. The Orde Lama period itself lasted from 1945 to 1965 under President Soekarno. The government during this period issued many policies on national education. After the proclamation, education in Indonesia was based on the 1945 Constitution and Pancasila which had just become the country's philosophy. One of them is Article 31 of the 1945 Constitution which regulates the implementation of education. For the education system, this period is carried on like the Japanese colonial era. However, the lesson plan is the same as in general and Indonesian is legalized as the official language of instruction for schools. It can be concluded that education in the Orde Lama era developed more significantly than before, as seen from the policies made in building a strong Indonesian national education structure.
\end{abstract}

Keywords: Education, Government Policy, Orde Lama.

Copyright (c) 2021 Hawa Kurnia, Hudaidah

$\triangle$ Corresponding author

Email : hawakrns@gmail.com

DOI : https://doi.org/10.31004/edukatif.v3i3.448

ISSN 2656-8063 (Media Cetak)

ISSN 2656-8071 (Media Online)

Edukatif : Jurnal Ilmu Pendidikan Vol 3 No 3 Tahun 2021 p-ISSN 2656-8063 e-ISSN 2656-8071 
840 Kebijakan Pemerintah Terhadap Kondisi Pendidikan di Indonesia Pada Masa Orde Lama (Periode 1945 1966) - Hawa Kurnia, Hudaidah

DOI: https://doi.org/10.31004/edukatif.v3i3.448

\section{PENDAHULUAN}

Penyelenggaraan pemerintahan di Indonesia secara resmi dimulai sejak 17 Agustus 1945 dengan diumumkannya kemerdekaan Indonesia ke dunia. Mulai dari ditetapkannya pancasila menjadi dasar negara, disahkannya UUD 1945, pemerintah juga mengeluarkan banyak kebijakan, salah satunya di bidang pendidikan. Pendidikan yang diselenggarakan di Indonesia dipengaruhi berbagai faktor, salah satunya terkait kebijakan politik pemerintahan. Kebijakan merupakan pertimbangan akal, tentunya suatu kebijakan bukan semata-mata merupakan hasil pertimbangan akal manusia. Namun demikian akal manusia merupakan unsur manusia yang dominan di dalam mengambil keputusan dari berbagai opsi dalam pengambilan keputusan kebijakan dan kebijaksanaan yaitu lebih menekankan pada faktor-faktor emosional dan erasional bukan berarti suatu kebijaksanaan itu tidak mengandung unsur-unsur rasional (Yanti, 2020:14). Di antara sistem kehidupan teresebut tersusunlah sistem pendidikan yang diinginkan oleh bangsa Indonesia bagi seluruh rakyatnya (Ismail, 2016: 144).

Pendidikan menyangkut proses transmisi ilmu pengetahuan dan budaya, serta perkembangan keterampilan dan pelatihan untuk tenaga kerja. Politik berkenaan dengan praktik kekuasaan, pengaruh dan otoritas, serta pembuatan keputusan-keputusan otoritatif tentang alokasi nilai-nilai dan sumberdaya. Karena keduanya syarat dengan proses pengalokasian dan pendistribusian nilai-nilai dalam masyarakat, maka tidaklah sulit untuk memahami bahwa pendidikan dan politik adalah dua aktivitas yang akan terus terkait dan saling berinteraksi (Hartono, 2016:35).

Pendidikan Indonesia pada masa orde lama dilihat dari sejarah, dibagi menjadi dua periode waktu, yaitu periode 1945-1950 dan periode 1950-1966. Dalam menyusun Undang-Undang, Dewan Konstituante hasil pemilu tahun 1955 dianggap belum berhasil dalam melakukan tugasnya. Akhirnya presiden Soekarno mengeluarkan dekrit presiden pada tanggal 5 juli 1959, salah satunya diberlakukannya kembali UndangUndang dasar 1945. Selanjutnya disusul juga dengan pidato dari Soekarno di tanggal 17 Agustus 1959 dengan judul Penemuan Kembali Revolusi Kita. Seiring dengan dikeluarkannya Dekrit Presiden, Soekarno juga mengajukan suatu konsep yang disebut "Demokrasi Terpimpin", yang kemudian berganti nama menjadi Manifesto Politik (Manipol). Pada era orde lama ini, ditekankan suatu kebijakan pendidikan yang merujuk kepada isu nasionalisasi dan ideologisasi. Filosofi pendidikan diwajibkan berdasarkan Pancasila dan Manipol (Manipesto politik) UUD1945 yang materinya berorientasi pada sosialisme dalam perspektif Indonesia (Zulkarnain, 2017:61).

\section{METODE}

Penelitian ini berbentuk penelitan kepustakaan (library research), yaitu serangkaian penelitian yang berkenaan dengan metode pengumpulan data pustaka, atau penelitian yang objek penelitiannya digali melalui beragam informasi kepustakaan (buku, ensiklopedi, jurnal ilmiah, koran, majalah, dan dokumen) (Syaodih, 2014). Kajian pustaka ini dilakukan penulis dengan mengkaji tulisan ilmiah seperti buku, artikel dan jurnal. Jumlah literatur yang dipakai sebagai bahan acuan penulis dalam kajian ini sebanyak 15 tulisan ilmiah yang berkaitan dengan kebijakan pemerintah terhadap pendidikan Indonesia pada periode orde lama (periode 19451966). Kemudian penulis mengidentifikasi titik temu dari data-data primer dan sekunder yang diperoleh mengenai kebijakan-kebijakan tersebut. Adapun harapan adanya kajian ini dapat memotivasi setiap individu dalam memajukan pendidikan di indonesia menjadi lebih baik. Metode ini dipilih penulis karena efektif untuk mengkaji dan menganalisis mengenai kebijakan pemerintah terhadap pendidikan di Indonesia pada masa orde lama, karena kajian ini dianalisis penulis setiap kejadian sesuai dengan urutan waktunya. 
841 Kebijakan Pemerintah Terhadap Kondisi Pendidikan di Indonesia Pada Masa Orde Lama (Periode 1945 1966) - Hawa Kurnia, Hudaidah

DOI: https://doi.org/10.31004/edukatif.v3i3.448

\section{HASIL DAN PEMBAHASAN}

Pasca kemerdekaan, negara Indonesia sedang giat-giatnya menata sistem kehidupan berbangsa dan bernegara dengan berlandaskan Pancasila serta UUD 1945. Banyak perubahan yang dilakukan, bukan hanya di bidang pemerintahan, namun terjadi di bidang pendidikan. Kebijakan pendidikan adalah bagian strategis yang dapat dilaksanakan dalam perbaikan kualitas pendidikan (Mukodi, 2016:38). Perubahan yang terjadi dalam bidang pendidikan merupakan perubahan yang bersifat mendasar, yaitu perubahan menyangkut penyesuaian kebijakan pendidikan dengan dasar dan cita-cita dari suatu bangsa yang merdeka dan negara yang merdeka. Oleh karena itu wujud kemerdekaan adalah cerminan dari cita-cita perjuangan bersama dari bangsa Indonesia dan karenanya bentuk, sistem, dan tata cara pemerintahan disusun atas dasar cita-cita dan kehendak bangsa Indonesia tersebut (Sudarmono, 2020:19). Untuk mengadakan penyesuaian dengan cita-cita bangsa Indonesia yang merdeka itulah maka pendidikan mengalami perubahan terutama dalam landasan idealnya, tujuan pendidikan, sistem persekolahan, dan kesempatan belajar yang diberikan kepada rakyat Indonesia (Muzammil, 2016:188).

Pancasila dijadikan sebagai pijakan suatu norma dasar dan sebagai norma tertinggi dalam penyelenggaraan kehidupan berbangsa serta bernegara di tanah air. Begitupun di bidang pendidikan, Pancasila menjadi landasan dalam pelaksanaan pendidikan pada masa orde lama. Pancasila adalah identitas dan karakteristik bangsa atau keperibadian nasional yang perwujudannya secara melembaga sebagai sistem pancasila yang menjiwai setiap keperibadian bangsa, pandangan hidup (keyakinan bangsa) sistem kenegaraaan dan masyarakat Indonesia (Zulkarnain, 2017:61).

Dalam menyusun Undang-Undang, Dewan Konstituante hasil pemilu tahun 1955 dianggap belum berhasil dalam melakukan tugasnya. Untuk mengembangkan sistem pendidikan kearah yang lebih baik, salah satu tolak ukur utama yang harus dilakukan adalah menghilangkan berbagai tindakan yang dapat merusak sistem (Haerullah, 2020:190). Langkah strategis yang diambil pemerintah Soekarno untuk mengurai kebuntuan politik saat itu adalah mengeluarkan dekrit yang terkenal dengan nama Dekrit Presiden pada Juli 1959. Salah satu isi dekrit adalah kembali kepada Undang-undang Dasar 1945 ("Ketika Kebijakan Orde Lama Memasuki Domain Pendidikan: Penyiapan Dan Kinerja Guru Sekolah Dasar Di Indonesia," 2014:106). Selanjutnya disusul dengan sebuah pidato Soekarno dengan judul "Penemuan Kembali Revolusi Kita" yang disampaikan pada tanggal 17 Agustus 1959.

Seiring dengan dua perihal tersebut, Soekarno juga mengajukan suatu konsep yang disebut Demokrasi Terpimpin, yang kemudian berganti nama menjadi Manifesto Politik (Manipol). Berdasarkan Penetapan Presiden Nomor 1 Tahun 1960 dan Tap MPRS Nomor I/MPRS/1960, Manipol ditetapkan sebagai Garis-garis Besar Haluan Negara dengan menambahkan USDEK. Sehingga mau tidak mau, pada masa itu harus diselenggarakan pendidikan yang Manipolis. Manusia sosialis Indonesia adalah cita-cita utama setiap usaha pendidikan Indonesia (Fadli \& Kumalasari, 2019:168).

Berpacu pada Manipol-Usdek terbentuk suatu kebijakan melalui intruksi PP \& K No. 1 tahun 1959. Instruksi tersebut ikenal dengan Pancawardhana dan Sapta Usaha. Adapun isi dari Pancawardhana yang berarti lima prinsip perkembangan (The Five Principles of Education), yaitu : Perkembangan cinta terhadap bangsa dan tanah air, terhadap moral nasional, internasional, dan terhadap keagamaan. Perkembangan terhadap inteligensi. Perkembangan pada emosional-artistik atau rasa keharusan dan estetika lahir batin. Perkembangan pada keprigelan (kerajinan) tangan. Perkembangan terhadap jasmani.

Pada hakikatnya, sistem pendidikan Pancawardhana berupa pendidikan dengan pemusatan pada pertumbuhan maupun perkembangan pribadi, serta bercorak nasionalistik guna memenuhi tuntutan revolusi Indonesia yang sedang berlangsung. Sapta Usaha Tama berisi tentang: penertiban aparatur dan usaha Kementerian PP \& K, menggiatkan kesenian dan olahraga, mengharapkan usaha halaman, mengharuskan penabungan, mewajibkan usaha-usaha koperasi, mengadakan kelas masyarakat, membentuk regu kerja di kalangan SLA dan universitas (Fadli \& Kumalasari, 2019:168). 
842 Kebijakan Pemerintah Terhadap Kondisi Pendidikan di Indonesia Pada Masa Orde Lama (Periode 1945 1966) - Hawa Kurnia, Hudaidah

DOI: https://doi.org/10.31004/edukatif.v3i3.448

Dilihat dari kurun waktunya, periode pendidikan dari pasca kemerdekaan hingga orde lama terbagi menjadi dua, yaitu periode 1945-1950 dan periode 1950-1966. Tata susunan persekolahan sesudah Indonesia merdeka yang berdasarkan satu jenis sekolah untuk tiga tingkat pendidikan seperti pada zaman Jepang tetap diteruskan sedangkan rencana pembelajaran pada umumnya sama dan bahasa Indonesia ditetapkan sebagai bahasa pengantar untuk sekolah. Buku-buku pelajaran yang digunakan adalah buku-buku hasil terjemahan dari bahasa Belanda ke dalam bahsa Indonesia yang sudah dirintis sejak jaman Jepang (Datumula, 2021:59).

Adapun satuan pendidikan pada periode 1945-1950, diantaranya sebagai berikut. Pendidikan Rendah.Tingkat pendidikan terendah pada masa itu dengan sebutan Sekolah Rakyat (SR). Tujuan dari SR sendiri ialah untuk menampung keinginan dan hasrat yang kuat untuk mereka yang ingin bersekolah guna meningkatkan kualitas ataupun taraf pendidikan yang lebih baik dari masa penjajahan. SR sendiri lebih ditekankan pada mata pelajaran bahasa serta berhitung sesuai dengan putusan Menteri PK \& K No 1153/Bhg A pada tanggal 19 November 1946. Hal ini dapat telihat bahawa dari 38 jam pelajaran seminggu, 8 jam adalah untuk bahasa Indonesia, 4 jam untuk bahasa daerah dan 17 jam berhitung untuk kelas IV, V dan VI. Tercatat sejumlah 24.775 buah SR pada akhir tahun 1949 pada akhir tahun 1949 di seluruh Indonesia (Datumula, 2021:59).

Pendidikan Guru.Pada periode ini juga, diketahui sudah terbentuk tiga jenis pendidikan untuk guru, yaitu : SGB (Sekolah Guru B) Tujuan dari SGB ialah untuk menghasilkan guru yang nantinya akan mengajar di SR dengan lama pendidikan 4 tahun. Murid yang dapat diterima ialah seorang tamatan dari SR yang dinyatakan lulus ujian sekolah lanjutan. SGC (Sekolah Guru C). Dikarenakan kurangnya jumlah guruh untuk SR, sehingga dibuka sekolah yang dapat menghasilkan guru dalam waktu yang singkat disebut dengan Sekolah Guru C (SGC). Namun adanya SGC ini masih belum dirasa berguna, sehingga sebagian SGC dijadikan SGB dan sebagian lainnya ditutup kembali. SGA (Sekolah Guru A). Sekolah Guru A (SGA) dbuka dengan alasan bahwa pendidikan selama 4 tahun dirasa belum bisa menjamin pengetahuan seorang pendidik dengan masa pendidikan tiga tahun setelah SMP. Terkait mata pelajaran di SGA terbilang sama dengan jenis mata pelajaran di SGB. Namun yang membedakan SGA ialaha pelaksanaannya yang lebih luas dan mendetail.

Pendidikan Umum. Pendidikan umum di periode 1945-1950 terbagi menjadi dua tingkatan, diantaranya : SMP (Sekolah Menengah Pertama) Rencana pembelajaran yang digunakan sama halnya seperti pada zaman penajajahan Jepang.. Namun pada periode ini, mulai dari kelas II diadakan suatu sistem pembagian kelas A dan B, sesuai dengan surat keputusan dari menteri PP \& K pada tahun 1946, maka terbentuk kelas II A, II B, III A serta III B. Terkait dengan mata pelajarannya, pelajaran mengenai ilmu alam dan juga ilmu alam di di kelas A lebih sedikit dibandingkan dengan kelas B, sebaliknya pelajaran tentang bahasa dan praktek administrasi di kelas B lebih sedikit daripada kelas A. SMT (Sekolah Menengah Tinggi) SMT berupa tingkatan pendidikan dengan lama pendidikannya tiga tahun yang dilaksanakan sesudah SMP dan apabila dinyatakan lulus SMT, siswa bisa melanjutkan studi ke perguruan tinggi. Untuk mata pelajaran pada SMT pada periode 1945-1950 ini terbilang belum jelas. Hal tersebut disebabkan pada masa ini kondisi zaman belum stabil. Demikian rencana pembelajaran yang berlaku yaitu: (1) isinya memenuhi kebutuhan nasional, (2) bahasa pengantarnya adalah bahasa Indonesia, (3) mutunya setingkat dengan SMT menjelang kemerdekaan. Ujian akhir dapat diselenggarakan oleh masing-masing sekolah selama belum ada ujian negara, tetapi setelah tahun 1947 barulah berlaku ujian negara tersebut (Datumula, 2021:60).

Pendidikan Kejuruan. Adanya pendidikan kejuruan pada masa ini difokuskan pada pendidikan kewanitaan serta pendidikan ekonomi. Berikut ini adalah sekolah kejuruan yang ada pada tahun 1945-1950. Pendidikan Kewanitaan. Sesudah kemerdekaan pemerintah membuka Sekolah Kepandaian Putri (SKP) dan pada tahun 1947 sekolah guru kepandaian putri (SGKP) yang lama pelajaranya empat tahun setelah SMP atau SKP (Datumula, 2021:61). Pendidikan Ekonomi Sekolah dagang dibuka pemerintah pasca kemerdekaan memiliki tujuan untuk memenuhi kebutuhan para tenaga di bidang pembukuan atau administrasi. Untuk lama pendidikan, sekolah dagang sendiri dilaksanakan selama tiga tahun sesudah lulus dari SR atau Sekolah 
843 Kebijakan Pemerintah Terhadap Kondisi Pendidikan di Indonesia Pada Masa Orde Lama (Periode 1945 1966) - Hawa Kurnia, Hudaidah

DOI: https://doi.org/10.31004/edukatif.v3i3.448

Rakyat. Pendidikan Teknik Seperti sekolah-sekolah yang lain, keadaan Sekolah Teknik juga tidak teratur dikarenakan para pelajaranya sering berpartisipasi dalam perihal pertahanan negara, Sekolah Teknik pada masa ini dapat dikatakan tidak teratur. Bahkan sekolah teknik ini dijadikan sebagai pabrik utnuk pembuatan senjata. Berikut ini beberapa jenis dari pendidikan teknik pada periode 1945-1950. STP (Sekolah Teknik Pertama) Dibukanya STP ini bertujuan untuk memperoleh tenaga seorang tukang ataupun kuli yang tidak hanya terampil tetapi tetapi juga memiliki pengetahuan teori mengenai teknik yang baik. Jurusan pada STP, seperti jurusan batu, kayu, keramik, anyaman, perabot rumah, listrik, cetak, dan besi dengan lama pendidikan selama dua tahun setelah SR. ST (Sekolah Teknik) Tujuan dari ST ialah untuk mendidik para tenaga dalam bidang pengawasan bangunan. Lama pendidikannya dua tahun sesudah STP atau SMP bagian B Jurusan pada ST terdiri dari bangunan air dan jalan, bangunan gedung, bangunan radio, percetakan dan pertambangan serta bangunan kapal dengan lama pendidikannya dua tahun setelah lulus dari SMP atau SMT bagian B. STM (Sekolah Teknik menengah). STM juga bertujuan untuk mendidik para pejabat teknik menengah dan tenaga ahli teknik dengan lama pendidikan lebih lama dari ST dan STP, yaitu empat tahun sesudah ST atau SMP bagian B. Jurusan yang ada di STM terdiri atas jurusan bangunan mesin, bangunan gedung, bangunan kapal, bangunan sipil, bangunan listrik, kima serta pesawat terbang. KKN (Kursus Kerajinan Negeri) Sekolah/kursus ini satu tahun lamanya dan Kursus ini ialah pendidikan teknik terendah setelah SR dengan lama pendidikannya selama enam tahun. Jurusan yang ada di KKN, ialah jurusan besi, kayu, anyaman, perabot rumah, batu serta jurusan las. Pendidikan guru untuk sekolah teknik.Adanya pendidikan guru sekolah teknik bertujuan dalam menghasilkan guru sekolah teknik yang dibutuhkan sekolah teknik itu sendiri dengan. Ada tiga jenis ijazah yang akan didapatkan seorang guru teknik dari sekolah ini yaitu Ijazah A Teknik (KGSTP) dalam jurusan mesin, bangunan sipil, listrik dan mencetak pada STP atau Sekolah Teknik Pertama. Kemudian Ijazah B I Teknik (KGST) dengan kewenangan mengajar di STM kelas I atau ST pada jurusan bangunan gedung, sipil serta mesin dan Ijazah B II Teknik untuk mengajar di STM dalam jurusan bangunan gedung, bangunan sipil, listrik dan mesin.

Pendidikan Tinggi. Ruang untuk masyarakat dalam melanjutkan pendidikan ke jenjang yang lebih tinggi semakin dapat dicapai. Namun kenyataannya pelaksanaan perkuliahn masih dilakukan di sela-sela waktu perjuangan dalam mempertahankan keaudalatan negara. Adapun lembaga pendidikan yang dibuka pada masa ini ialah Universitas Gajah Mada serta beberapa akademi dan sekolah tinggi dan akademi di Klaten, Yogyakarta, Jakarta dan Solo.

Pada periode 1950-1966, bisa dikatakan hanya meneruskan dan pengimplementasian kebijakan mengenai tatanan pendidikan yang telah di atur sedemikian rupa pada periode 1945-1950 sebelumnya. Motto revolusi terhadap pendidikan nasional dimulai dari perihal yang paling mendasar. Di bawah kepemimpinan pemerintahan Soekarno, dirasa sudah cukup dalam memberikan kesempatan pendidikan sebagai wujud suatu interpretasi setelah proklamasi. Pemerintahan yang berasaskan sosialisme menjadi rujukan dasar bagaimana pendidikan akan dibentuk dan dijalankan demi pembangunan dan kemajuan bangsa Indonesia di masa mendatang. Pada prinsipnya konsep sosialisme dalam pendidikan memberikan dasar bahwa pendidikan merupakan hak semua kelompok masyarakat tanpa memandang kelas sosial. Pada saat inilah merupakan suatu era di mana setiap orang merasa bahwa dirinya sejajar dengan yang lain, serta setiap orang memiliki hak untuk mendapatkan pendidikan. Orde lama berusaha membangun masyarakat sipil yang kuat, yang berdiri di atas demokrasi, kesamaan hak dan kewajiban antara sesama warga negara, termasuk dalam bidang pendidikan (Datumula, 2021:63).

Orde lama berupaya membentuk masyarakat yang kuat, mampu berdiri di atas demokrasi, dan berhak mendapatkan kesamaan antara hak dan kewajibannya antar sesama warga, termasuk juga dalam bidang pendidikan. Pada dasarnya hal ini sudah dikatakan dalam pembukaan UUD 1945 berisi cita-cita dari pembangunan nasional, yaitu mencerdaskan kehidupan bangsa. Tujuan pendidikan di selain mencerdaskan kehidupan warganya, di sisi lain, bertujuan menjadikan manusia Indonesia seutuhnya (Sartini, 2014:342). 
Adanya tujuan nasional tersebut mengakibatkan bahwa kewajiban mencerdaskan bangsa melekat pada eksistensi negara. Dengan kata lain, bahwa untuk mencerdaskan kehidupan bangsalah maka negara Indonesia dibentuk (Triningsih, 2017:340-341).

Kebijakan dan Undang-Undang yang telah dibuat, dirasa sangat berpengaruh terhadap sistem pendidikan dan pembelajaran di tanah air. Di bawah pemikiran menteri pendidikan yang pertama, Ki Hadjar Dewantara mengembangkan penyelenggaraan pendidikan dengan nama sistem among yang berlandaskan asas kemerdekaan, kebudayaan, kemanusiaan, kodrat alam dan kebangsaan yang kita kenal dengan sebutan Panca Dharma Taman Siswa. Pemerintah juga membuat banyak peraturan pendidikan, yaitu UU No. 4/1950 disempurnakan menjadi UU No. 12/1954 mengenai dasar pendidikan. Kemudian di tahun 1961 disahkan lagi UU No. 22/1961 tentang Pendidikan Tinggi, dilanjutkan dengan adanya UU No.14/1965 tentang Majelis Pendidikan Nasional, serta UU No. 19/1965 mengenai pokok sistem pendidikan berlandaskan pancasila. Nilai-nilai yang terkandung dalam Pancasila yang dijadikan landasan dan filosofi dalam kehidupan bermasyarakat,berbangsa dan bernegara juga dikemukakan secara jelas oleh Presiden pertama Indonesia Sukarno (Zulkarnain, 2017:59).

Kebijakan pemerintah terhadap pendidikan tidak lepas dari kondisi dan situasi politik suatu negara yang dilakukan oleh kekuatan sosial yang ingin mengedalikan pemerintahan tersebut. Sebenarnya, kajian politik pendidikan terkonsentrasi pada peranan pemerintah dalam bidang pendidikan, sehingga dapat menjelaskan asumsi dan maksud dari berbagai strategi perubahan pendidikan dalam suatu masyarakat secara lebih baik (Hoddin, 2020:18). Tatanan sistem pendidikan di masa Orde Lama masih banyak dipengaruhi oleh keadaan politik negara Indonesia pada saat itu dibawah kendali utama oleh tokoh-tokoh nasionalis. Oleh sebabnya, banyak kejadian yang mengakibatkan goyahnya kestabilan pemerintah kala itu. Salah satunya pada sistem parlemen dengan banyaknya partai yang saling sikut menyikut untuk perihal kekuasaan, mengakibatkan sistem parlemen sukar bekerja sama dengan baik dalam membuat rancanganan sistem pendidikan nasional. Yang pada akhirnya parlemen dibubarkan oleh Soekarno lewat dekrit presiden dan diberlakukan kembali UUD 1945 guna menstabilkan kondisi politik yang berpengaruh besar pada bidang pendidikan saat itu.

Jika ditinjau dari segi kebijakan, pemerintah orde lama menetapkan Pancasila dan Manipol USDEK sebagai asas pendidikan nasional Indonesia. Tetapi pada kenyataannya pendidikan yang berlandaskan pancasila, baru penentuan saja. Belum diterapkan tentang bagaimana meletakkan dasar itu pada struktur pelaksanaan pendidikan dan pengajaran. Jargon Manipol USDEK diindoktrinasikan ke setiap lapisan masyarakat di semua tingkatan pendidikan, sehingga tidak diperbolehkan adanya penafsiran lain selain dari pemerintah. Dampaknya tujuan pendidikan ikut berubah dari menghasilkan manusia susila dan demokratis berjiwa pancasila menjadi manusia susila yang sosialis dan menjadi pelopor dalam membela ManipolUSDEK. Namun di balik kekurangannya, dengan semangat kemerdekaan pemerintah orde lama terus menerus belajar membentuk kebijakan-kebijakan guna membangun serta mewujudkan suatu negara, juga dalam perihal berdemokrasi dan menyelenggarakan tatanan pendidikan Indonesia yang lebih baik.

\section{KESIMPULAN}

Kebijakan dan penyelenggaraan pendidikan tak mungkin lepas dari kondisi politik. Pendidikan sering dijadikan alat untuk mengiring masyarakat mengarah pada tujuan politik yang diinginkan oleh negara. Penyelenggaraan pendidikan di tanah air yang berlandaskan Pancasila pada masa orde lama di mulai sejak dikumandangkannya proklamasi kemerdekaan. Indonesia pada masa orde lama merupakan negara yang sarat akan cita-cita sosialisme, sehingga kebijakan pendidikan pada masa orde lama juga harus selaras yaitu pendidikan sosialisme. Politik dan pendidikan di Indonesia terlihat sedemikian erat. Kegiatan-kegiatan kependidikan sudah banyak dipengaruhi oleh para penguasa dengan tujuan untuk mempertahankan kekuasaan mereka. Kebijakan pendidikan sudah menjadi tema kompetisi antar partai politik di parlemen yang 
845 Kebijakan Pemerintah Terhadap Kondisi Pendidikan di Indonesia Pada Masa Orde Lama (Periode 1945 1966) - Hawa Kurnia, Hudaidah

DOI: https://doi.org/10.31004/edukatif.v3i3.448

mengakibatkan tatanan pendidikan pada saat itu menjadi tidak stabil. Para pengambil kebijakan lebih disibukkan kepada hal-hal lain, mereka lupa bahwa ketika Indonesia sudah merdeka seharusnya perdebatan utama justru pada tatanan pendidikan bukan konstitusi kenegaraan saja. Kebijakan pada periode ini ditujukan pada proses indoktrinasi yang menolak semua pengaruh dari luar. Bahan-bahan yang diberikan bukan hanya pancasila dan UUD 1945, tetapi juga diisi dengan pandangan politik penguasa waktu itu. Sejarah mencatat bahwa apa yang telah dilakukan oleh rezim orde lama dipandang sebagai suatu upaya indoktrinasi. Konsep pendidikan ini, akhirnya berakhir pada tahun 1965 ditandai dengan turunnya Soekarno dari kursi kepresidenan.

\section{DAFTAR PUSTAKA}

Datumula, S. (2021). PERATURAN KEBIJAKAN PENDIDIKAN DI INDONESIA PADA MASA ORDE LAMA, ORDE BARU, REFORMASI, DAN KABINET KERJA. Moderasi: Jurnal Studi Ilmu Pengetahuan Sosial, 1(2). https://doi.org/10.24239/moderasi.vol1.iss2.27

Fadli, M. R., \& Kumalasari, D. (2019). Sistem Pendidikan Indonesia Pada Masa Orde Lama (Periode 19451966). AGASTYA: JURNAL SEJARAH DAN PEMBELAJARANNYA, 9(2). https://doi.org/10.25273/ajsp.v9i2.4168

Haerullah, H. (2020). Dimensi Perkembangan Pendidikan Formal dan Non Formal. Jurnal Edukasi Nonformal, 1(2), 190-207. https://ummaspul.e-journal.id/JENFOL/article/view/504

Hartono, Y. (2016). Pendidikan Dan Kebijakan Politik (Kajian Reformasi Pendidikan Di Indonesia Masa Orde Lama Hingga Reformasi). AGASTYA: JURNAL SEJARAH DAN PEMBELAJARANNYA, 6(01). https://doi.org/10.25273/ajsp.v6i01.879

Hoddin, M. S. (2020). Dinamika Politik Pendidikan Islam Di Indonesia; Studi Kebijakan Pendidikan Islam Pada Masa Pra-Kemerdekaan hingga Reformasi. Jurnal Ilmiah Iqra', 14(1). https://doi.org/10.30984/jii.v14i1.1035

Ismail. (2016). POLITIK PENDIDIKAN ISLAM ORDE LAMA 1945-1965 (Study Kebijakan Pemerintah Dalam Penyelenggaraan Pendidikan Islam). Kabilah, $1(1)$.

KETIKA KEBIJAKAN ORDE LAMA MEMASUKI DOMAIN PENDIDIKAN: PENYIAPAN DAN KINERJA GURU SEKOLAH DASAR DI INDONESIA. (2014). Paramita - Historical Studies Journal, 24(1). https://doi.org/10.15294/paramita.v24i1.2867

Mukodi. (2016). Dinamika Kebijakan Pendidikan di Indonesia Sebuah Refleksi Historis. Dinamika Pendidikan Dan Masa Depan Keindonesiaan, 38.

Muzammil, A. (2016). KEBIJAKAN PEMERINTAH DALAM BIDANG PENDIDIKAN DARI ORDE LAMA SAMPAI ORDE BARU (Suatu Tinjauan Historis). POTENSIA: Jurnal Kependidikan Islam, 2(2). https://doi.org/10.24014/potensia.v2i2.2537

Sartini. (2014). KEBIJAKAN PENDIDIKAN DAN PENDIDIKAN DEMOKRASI Perspektif Sejarah Otonomi Pendidikan di Indonesia. Sosio E-Kons, 6(1).

Sudarmono, M. A. (2020). TINJAUAN SEJARAH PENDIDIKAN ISLAM MASA ORDE LAMA. KREATIF: Jurnal Studi Pemikiran Pendidikan Agama Islam, 18(1). https://doi.org/10.52266/kreatif.v18i1.359

Syaodih, N. (2014). Penelitian Deskriptif Kualitatif. Tripven.

Triningsih, A. (2017). Politik Hukum Pendidikan Nasional: Analisis Politik Hukum dalam Masa Reformasi. Jurnal Konstitusi, 14(2). https://doi.org/10.31078/jk1425

Yanti, S. (2020). Analisis Kebijakan Pendidikan. Lentera: Indonesian Journal of Multidisciplinary Islamic Studies, 1(1). https://doi.org/10.32505/lentera.v1i1.1662 
846 Kebijakan Pemerintah Terhadap Kondisi Pendidikan di Indonesia Pada Masa Orde Lama (Periode 1945 1966) - Hawa Kurnia, Hudaidah

DOI: https://doi.org/10.31004/edukatif.v3i3.448

Zulkarnain, Z. (2017). Filosofis Kurikulum Mata Pelajaran Sejarah Masa Orde Lama. Historia: Jurnal Pendidik Dan Peneliti Sejarah, 1(1). https://doi.org/10.17509/historia.v1i1.7011 